\title{
Beef Cattle Value Chain Analysis in Bora and Dugda Districts, Oromia Regional State, Ethiopia
}

\author{
Solomon Ayele ${ }^{1^{*}} \quad$ Lemma Zemedu $(\mathrm{PhD})^{2} \quad$ Berhanu Gebremdhin $(\mathrm{PhD})^{3}$ \\ 1.Agricultural Economics, Fedis Agricultural Research Center, Oromia Agricultural Research Institute, \\ P.O. box 904, Harar, Ethiopia \\ 2.Agricultural Economist, College of Agriculture and Environmental Science, Haramaya University, P.O. box \\ 138, Dire Dawa, Ethiopia \\ 3.Agricultural Economist, International Livestock Research Institute (ILRI), P.O. box 5689, Addis Ababa, \\ Ethiopia
}

The research is financed by International Livestock Research Institute (ILRI)/Livestock and Irrigation Value chain for Ethiopian Smallholders (LIVES) Project

\begin{abstract}
This study was aimed at analyzing beef cattle value chain in Bora and Dugda districts, Oromia Regional State, Ethiopia. The specific objectives of the study were to identify major beef cattle value chain actors and their roles in beef cattle value chain in the study areas and the major constraints and opportunities in beef cattle value chain. About 120 smallholder beef cattle producers were selected randomly from the five kebeles administrations proportionally. Descriptive statistics were used to analyze the collected data. The value chain analysis results showed that the major value chain actors in the study areas are input suppliers, producers, traders, small feedlot operators, processors/butcheries, hotels and restaurants, and consumers. The study results also revealed that feed shortage, high prices of feed, disease outbreak and poor managements were the major constraints that farmers were faced on behalf of production side. From market side, market price instability, low price offered for the commodity and involvement of intermediatiaries were the major constraints. Improving beef cattle production and management through provision of effective extension services, inputs, strengthening farmers' value addition (fattening) to beef cattle at farm level and developing efficient value chain were recommended for policy implications.
\end{abstract}

Keywords: Beef cattle, Value chain and Bora and Dugda Districts

DOI: $10.7176 / \mathrm{FSQM} / 87-03$

Publication date:May $31^{\text {st }} 2019$

\section{Introduction}

In Ethiopia, agriculture is the main economic activity and more than $80 \%$ of population is dependent on agriculture in which livestock play a very important role. In Ethiopia, agriculture contributes about $50 \%$ to the overall gross domestic product (GDP), generates $90 \%$ of export earnings, and provides employment for $80 \%$ of the population. Within agricultural subsector, livestock contributes 15 to $17 \%$ of GDP, 35 to $49 \%$ of agricultural GDP, 37 to $87 \%$ of the household incomes and 16-19\% of total foreign exchange earning of the country (CSA, 2013). ). However, the contribution of this subsector in the national and agricultural economy of the country is low due to feed shortage, weak breed selection practice, insufficient market infrastructure, weak farm to market linkages and insufficient veterinary services are the major challenges livestock-dependent people (IGAD, 2011).

In Ethiopia, both farming and pastoral households are largely dependent on livestock for their livelihood systems. Livestock have diverse functions in the livelihood of Ethiopian farmers in the various farming system and serves as a source of food, traction, manure, raw materials, investment, cash income, foreign exchange earnings and social and cultural identity (Belete et al., 2010). Among livestock species, cattle contribute significantly to the livelihoods of farmers. They serve as a source of draught power for the rural farming population, supply farm families with milk, meat, manure, and also as source of cash income, playing a significant role in the social and cultural values of the society.

The livestock value chain can be defined as the full range of activities required to bring a product (e.g. live animals, meat, milk, eggs, leather, fibber, manure) to final consumers passing through the different phases of production, processing and delivery. It can also be defined as a market-focused collaboration among different stakeholders who produce and market value-added products (IFAD, 2010). Livestock value chain analysis here is essential to an understanding of markets, their relationships, the participation of different actors, and the critical constraints that limit the growth of livestock production and consequently the competitiveness of smallholder farmers. The entire beef cattle value chain in Ethiopia is further characterized by numerous intermediaries /actors namely: brokers, collectors; agents; animal trekkers, small, medium and big traders; wholesalers; abattoirs; butcheries; exporters; local authority and department of Veterinary services. This makes the chain unnecessarily long with increased transaction costs and without significant value added activities (Negassa et al., 2011). 
In the study areas beef cattle are one of a few agricultural commodities from which the producers are relied their livelihood and obtain their income to fulfill their needs and economic gaps. Only a small fraction of beef cattle is raised in feedlots. Smallholders are fattening their beef cattle in backyard system. The majority of the producers are uses oxen for draught purpose, and then after finishing draught and become too old they sell for beef purpose. Additionally, barren cows, heifers and bulls are used for beef. But, mostly heifers and bulls are used for restocking.

Although, these study areas are known for their major source beef cattle suppliers; feed and water problem, poor beef cattle husbandry and management, less transparency of market information, high cost of inputs, poor market infrastructure, and low capacity of slaughter houses are the major problems that start from input supply to the final consumption in the study areas. Due to these reasons most of the beef cattle supplied to the market is domestically consumed and very few is available for export due to low quality (LIVES, 2013). In addition to above problems, there is a little competition among the beef cattle traders; the market and pricing power is retained by traders, there are many unlicensed traders, brokers and traders within the beef cattle value chain who takes high profit than the producers. There is also weak linkage among the beef cattle value chain both horizontally and vertically.

Analyzing value chain is essential to explain the connection between all the actors in a particular chain of production and distribution, who adds value and where along the chain, and to identify constraints and make improvements in weaker links where returns are low in the study areas. But, given the potential for beef cattle production, processing, marketing and consumption, there is scanty of information or no formal research conducted on the beef cattle value chain analysis in the study areas. Therefore, this paper was aimed to conduct beef cattle value chain analysis in Bora and Dugda districts, Oromia Regional State, Ethiopia with the specific objectives to identify major beef cattle value chain actors and their roles, and the major constraints and opportunities in beef cattle value chain in the beef cattle value chain in the study areas.

\section{Research Methodology}

\subsection{Description of the Study Areas}

Dugda district: Is composed of 36 rural kebeles and 3 urban kebeles and the district is located about $260 \mathrm{~km}$ south of Addis Ababa and 160km east of Adama town. Dry weina-dega and weina-dega which covers about 55\% and $45 \%$, are characterize agro-ecological zones of the district climate respectively. The altitude of the district ranges from 1600 to 2020 meters above sea level. The annual average temperature is $25^{\circ} \mathrm{c}$ whereas the minimum and maximum temperature is $22^{\circ} \mathrm{c}$ and $28^{\circ} \mathrm{c}$ respectively. The district receives average annual rainfall of $750 \mathrm{~mm}$, which is bimodal and erratic in distribution. The main rainy season of the district is from February to mid-May and from July to end of August. The economy of the district is dominated by crop farming mixed with livestock husbandry.

Bora district: Is composed of 18 rural kebeles and the district is located about $238 \mathrm{~km}$ south of Addis Ababa and $138 \mathrm{~km}$ east of Adama town. Dry Weina-Dega covers about 100\% characterize agro-ecological zones of the districts climate. The altitude of the district ranges from 1650 to 2020 meter above sea level. The annual average temperature is $25^{\circ} \mathrm{c}$ whereas the minimum and maximum temperature is $22^{\circ} \mathrm{c}$ and $28^{\circ} \mathrm{c}$ respectively. The district receives annual rainfall of 750-805 $\mathrm{mm}$, which is bimodal and erratic in distribution. The main rainy seasons are from February to mid-May and from July to end of August. The economy of the district is dominated by traditional cash crop farming mixed with livestock husbandry.

\subsection{Types, sources and Data collection Methods}

The survey data used for this study was collected from primary and secondary sources. The survey was undertaken through formal interviews with randomly selected farmers, traders and processors (butcheries and hotels) using a semi-structured questionnaire for each group. Additionally, primary data was collected from input suppliers and service providers through a key informant interview. The secondary data was also collected from Districts Bureau of Agriculture and Natural Resource Development, Districts Bureau of Livestock and Fishery Resource Development, Districts Bureau of Trade and Market Development; Livestock \& Irrigation Value chain for Ethiopian Smallholders Project (LIVES), Central Statistical Agency (CSA), and other published and unpublished sources.

\subsection{Sampling Method and Sampling Size Determination}

A multi-stage sampling technique was used to select representative farmer households from the study areas. In the first stage, Dugda and Bora districts were selected purposively based on its potential for beef cattle production and LIVES project intervention districts. In the second stage, with the consultation of district livestock experts and development agents, out of 36 and 18 kebeles from Dugda and Bora districts, three and two sample beef cattle producers kebeles namely Abona-Gebrel, Dodota Dambel, Wayo-Gebrel and, Barta-Sami and Malima-Bari kebeles were purposively selected based on their beef cattle production potential and road 
accessibility to conduct survey respectively. In the third stage, from total list of beef cattle producers in both districts about 120 sample households were randomly selected. The sample size was determined by using Yemane (1967) simple formula.

$$
\boldsymbol{n}=\frac{\boldsymbol{N}}{1+N\left(e^{2}\right)}
$$

Where, $(\mathrm{n}=$ Sample size $=120, \mathrm{~N}=$ Population size $=5,938$ and $\mathrm{e}=$ Level of precision assumed $9 \%(0.09))$.

In addition to the producers, primary data was also collected from the beef cattle traders at different levels. The traders' survey was conducted at districts market towns during the market days where transaction takes place. Here, sampling was the very difficult task due to absence of recorded lists of population of traders. Hence, interview was conducted with purposively selected beef cattle traders, small feedlot operators, butcheries and hotels, individual farmers who were purchased beef cattle for draught purpose at the market place. Both licensed and unlicensed traders were also included in the traders' survey. As a result, totally 16 beef cattle traders, 9 butcheries and hotels, 4 small feedlot operators, and 10 individual farmers were purposively selected and interviewed from both districts. Furthermore, 10 and 6 consumers were interviewed from Dugda and Bora Districts, respectively by selecting randomly.

\subsection{Methods of Data Analysis}

Descriptive statistics such as mean, standard deviation, frequencies, percentages and additionally tables were used to analysis the data collected from producers, traders and consumers.

\section{Results and Discussion}

\subsection{Socio-Economic characteristics of beef cattle producers}

From the total sample respondents, $82 \%$ were male-headed households and only $18 \%$ were female-headed in Dugda district and 90\% were male-headed households and 10\% were female-headed in Bora district. Sex of the household head in the two districts was significant difference at 10 percent significance level. The survey results revealed that the education level of households' showed there was a variation between the two districts and significant difference at 1 percent significance level. About 97 percent of the respondents in Dugda district were attended formal education, whereas it was $85 \%$ in Bora district. Regarding marital status of the household heads more respondents in Dugda and Bora districts were 94\% married (Table 1\&2).

Average household heads age was 42.5 and 41.2 years in Dugda and Bora districts respectively. The average family size of the total sample respondents was found to be 7 and 6 persons in Dugda and Bora districts respectively. Family size also showed variation at 5 percent significance level. With regards to farm experience, 13.97 and 15.19 average years of farming experience in beef cattle production/rearing both in Dugda and Bora districts respectively.

\subsection{Socio-Economic characteristics of beef cattle traders}

About $100 \%$ and $94 \%$ of the traders were male-headed households both in Bora and Dugda districts respectively. Only 4\% were female-headed in Dugda district. The survey results revealed that the education level status of the traders shows there were no variations between the two districts. Only 8 percent of the total respondents were illiterate whereas $92 \%$ were literate. Regarding marital status $100 \%$ and $94 \%$ of respondents in Bora and Dugda districts were married respectively. Only $6 \%$ of the traders were single in Dugda district. Average household heads age was 40 and 41 years in Bora and Dugda districts respectively. The average family size of the total sample respondents was found to be 6 and 5 persons in Dugda and Bora districts respectively. With regards to market experience, 7 average years of marketing experience in beef cattle trading both in Dugda and Bora districts. Table-3 summarizes the demographic characteristics of sampled traders in Dugda and Bora districts.

\subsection{Farmers' Access to Institutional Services}

Access to institutional support services for all actors in the value chain is pivotal to make the chain actors and the market chain as a system competitive so that producers, intermediaries and end users of goods and services can make the best use out of it. In this section support services of extension, credit and input supply were discussed. 3.3.1. Access to Extension Services About $96 \%$ and $91.04 \%$ of the respondents in Bora and Dugda districts were received extension services for beef cattle production (Table 4). The training provided by different institution shows that there was statically significant difference at 1 percent significance level between the two districts. This might be due to most of the respondent trainees in Dugda district has been trained by the districts experts or extension officers who closely follow up and provide advices to the farmers $(85 \%)$ from the total respondent farmers who received training than Bora district (15\%).

3.3.2. Access to Credit Services

About $96 \%$ and $89.5 \%$ of the sample respondents were accessed to credit services both in Bora and Dugda 
districts respectively. About $94 \%$ and $89 \%$ of farmers were received credit from formal credit institutions for beef cattle production from Bora and Dugda districts respectively, whereas only $6 \%$ and $11 \%$ farmers received from local money lenders in Bora and Dugda districts respectively (Table 4).

3.3.3. Access to Input Supply

Inputs used by farmers of the study areas for beef production were veterinary drugs, veterinary services, Artificial Insemination (AI), improved breed bull services and feed. These inputs are supplied to farmers either by governments, private traders or own. The result of this study shows that about $92.45 \%$ and $92.25 \%$ of the respondents used or accessed to inputs both in Bora and Dugda districts respectively (Table 4). The survey result indicated that most of the animal healthy veterinary services and veterinary drugs $(93 \%$ and $88 \%)$ are rendered by government both in Bora and Dugda districts respectively. Crop residues (teff and wheat straw) and grazing have become the main sources of feed for livestock both in Bora and Dugda districts. About $84 \%$ and $81 \%$ of the sampled respondents replied that they supply or prepare feed for their livestock by their own both in Bora and Dugda districts respectively. Only $16 \%$ and 19\% of the respondents were purchased by-product feed from the private traders with high price for fattening purposes both in Bora and Dugda districts respectively.

This survey result revealed that about $85 \%$ and $90 \%$ of the cattle population are local breeds both in Bora and Dugda districts respectively. The remaining were hybrids that accounted for about 15 percent and 10 percent, respectively in Bora and Dugda districts particularly for milk purposes. With regards to bull services the main source about $92 \%$ was local bull breed.

\subsection{Beef cattle value chain analysis}

3.4.1. Beef cattle value chain Map

Value chain mapping enables to visualize the flow of the product from conception to end consumer through various actors. It also helps to identify the different actors involved in the beef cattle value chain, and to understand their roles and linkages. Consequently, the current value chain map of beef cattle in Bora and Dugda districts was described in (Figure 1).

3.4.1.1. The major value chain actors and their roles

The major actors involved in beef cattle value chain in the study areas were input suppliers, producers, processors, cattle traders, small feedlot operators, individual farmers (other farmers) who purchased for draft purposes, and consumers. Accordingly, these major actors and their roles in beef cattle value chain were discussed below.

Input Suppliers: Inputs such as veterinary drugs were supplied by the districts livestock and fishery resource development offices and veterinary drug shops. Alema koudjis was the only supplier of different types of concentrate feeds for different purposes (fattening, milk and others). Most of the interviewed producers in the study areas were produce their own local breeds, but only few NGOs provided improved bull for few farmers organized in group.

Producers: In this value chain analysis, producers are the main suppliers of beef cattle to the different actors of the value chain in the study areas. Accordingly, smallholder beef cattle farmers are the major producers and suppliers $(100 \%)$ in the study areas. There is no commercial or ranches in the study areas.

Traders: The majority of transactions are completed by brokers and traders in both districts. In the study areas beef cattle traders were identified as small and large traders. Small traders were purchased beef cattle from the producers and sold to different actors (small-feedlot operators, large traders, butcheries and hotel owners, individual farmers for draft purposes). According to this study result small traders purchased on average 6 beef cattle per week at districts markets. They have no specific standards that they look for apart from the body size of beef cattle. They are large in numbers relatives to larger traders. They have limited working capital and even they borrowed from informal money lenders to run their business. The larger traders were purchased beef cattle mostly from small traders and producers then sold to the traders or consumers out of the areas and local butcheries. However, they are few in number compared to small traders.

Trekkers: beef cattle can be transported either by trekking or trucking. Smallholder farmers usually trek their beef cattle to the market. The distance varies according to their location from the market. In the case of the study areas about $53 \%$ and $83 \%$ of the market participant respondents replied that they use trekkers to transport their cattle to the district or secondary market both in Bora and Dugda districts respectively. They paid them 15-20 birr/head depending on the distance from the market. The remaining about $47 \%$ and $7 \%$ of the respondents transport their beef cattle to the district market by their own both in Bora and Dugda districts respectively.

Small feedlot operators: Small feed lot operators purchase on average two-three beef cattle mostly older oxen and, then fattened for three to four month targeting holiday markets. They purchased beef cattle either from the producers or small traders at districts markets and sold to their customer (butcheries and hotel owners). In the study areas few emerging small feedlot operators are operating the fattening practices around peri-urban and urban areas, particularly in Dugda district. In Dugda district only two modern large feedlot operators are participating in fattening targeting to export market, they purchase Borena cattle due to fulfills export standards. 
In the study areas mostly beef cattle are consumed domestically.

Butcheries: According to the districts former Trade and Industry Offices, now Trade and Market Development Bureau there are 19 and 10 butcheries and hotels that are processing beef and beef by-products both in Dugda and Bora districts respectively. There is no butcheries which alone to act as meat supplier to hotels, cafeterias and restaurants in the study areas. That mean in the study areas the hotel owners have their own butcheries. They sell on a retail basis but also serve meat on their premises as raw meat as well as roasted meat products. They were sold to hotels and restaurants. They were purchased from producers, small traders, feedlot operators and rarely from big traders at districts markets.

Individual farmers: In the study areas the individual farmers were identified as one of the beef cattle value chain actor and also served as one the farmers' beef cattle market outlets choices. They purchase heifer and young bulls for breeding and replacement purposes and mainly oxen for draft purpose from either producers or small traders at farm gate or district market place. After finishing with draught purpose they were market for beef purpose at older age.

Consumers: These were the final actors in the beef cattle value chain. They were domestic consumers who buy either processed meat from butchers and hotels or who, as a group buy beef cattle to slaughter and then share the meat particularly during holidays and other social occasions. They purchased beef cattle either from producer or small traders.

3.4.1.2. Value chain support actors or service providers

The only suppliers of veterinary services were provided by the districts Livestock and Fishery Resource Development Offices in the study areas. There are animal health clinics, approximately one for every 3 kebles, and animal health assistants are responsible for the diagnosis of the disease and treatments in the form of vaccination as-needed. These services were diagnosis, treatment and castrations. Oromia Saving and Credit Share Company, Busa Gonofa Micro finance and local money lenders were provided credit services for the producers and traders at various levels. Different NGOs and Projects were provided a variety of trainings to the producers. For instance, SIDA and LIVES Project implement different activities for cattle farmers. SIDA have provided bull extension service, and LIVES have provided different training in order to improve the capacity of the experts and the farmers in the study areas.

Districts Market and trade development offices were provided business licenses and commercial registrations for traders at various levels. They also control unlicensed traders to create competitive market among the traders. Municipalities were provided meat inspection and slaughtering services for butchers and hotel owners as well as public in general. They follow sanitary facilities and inspected meat for consumption.

3.4.1.3. Value chain enabling environments

Ministry of Livestock and Fishery Resource Development and Oromia bureau agriculture and rural development set the policies and regulatory issues like animal health and facilitating basic infrastructure through districts Livestock and Fishery Resource Development Offices at macro-level actors. Ministry of Trade and Industry set business rules and regulations policies at macro-level actors and implements through district Market and Trade Development Offices.

3.4.2. Beef cattle value chain governance

In the study areas market rules and regulations of beef cattle market was administered by the districts municipalities. The beef cattle value chain in the study areas was dominated by traders and butchers who are exercising considerable power on the chain and share large volume of sales but the business operations among the actors are uncoordinated. In the market places, brokers also exercise a great deal of power, as the majority of transactions are conducted with their assistances. But, the producers do have a small amount of power in that they have some ability to control when and to whom they sold their beef cattle.

In the study areas there was a clear vertical linkage among beef cattle farmers, traders and beef cattle processors in terms of buying and selling activities. These links were only market interactions. However, when considering information and services follows among different value chain actors' vertical linkages were weak. There were no horizontal linkages among the farmers. That means farmers were not organized as cooperatives or farmers groups particularly for beef cattle market in the study areas. However, there is a horizontal linkage among the beef cattle traders.

3.4.3. Constraints and Opportunities in the Beef cattle Value chain

The major production constraints which hindering the success of beef cattle value chain in the study areas were feed shortage, feed price increment, diseases outbreak, shortages of veterinary drugs, shortage of availability of water and poor management (Table 5). Price instability, low price offered for farmers, brokers and less accessed to market information were the major market constraints (Table 6).

The major beef cattle marketing constraints mentioned by traders were related with the financial problem, the problem of supply shortage, low product quality and lack of support from concerned bodies, and competition with unlicensed traders (Table 7).

During the survey time the data was collected from private veterinary drug shops, Busa-Gonofa micro- 
finance, Oromia Saving and Credit Association and Alema koudijs feed private limited company using key informant interviews. Supply shortage of drug, high prices of drugs, lack of awareness on new drug, competition with illegal traders, lack of experts on selling (prescription) and low market control on drug (inspection) are the major private veterinary drug suppliers' problems in the study areas. Lacks of farmers' awareness on the credit, unwillingness to take credit due to fearing of inability to repay and supply shortage were the major financial problems. Lack of farmers' awareness on concentrate feed is a problematic for improved feed supplier.

Availability of high population of livestock, excess of human labor, existence of crop residue as source of feed, existence of factory by-product concentrate feed, favorable condition for fattening, availability of veterinary services, accessibility are the major beef cattle production opportunities in the study areas. High domestic demand for beef product (meat) consumption during festivals, social occasions and increasing population growth (urban consumers) may create market opportunities for beef cattle value chain actors in the study areas.

\title{
4. Conclusion and Recommendations
}

This study was aimed at analyzing beef cattle value chain in Bora and Dugda districts, Oromia Regional State, Ethiopia. Specific objectives of the study were to identifying the main value chain actors and their roles in beef cattle value chain and the major constraints and opportunities in beef cattle value chain. Data were collected from 120 farmers' household heads and analyzed using descriptive statistics. The beef cattle value chain map in the study areas consisted main value chain actors were input/service suppliers, producers, beef cattle traders, small feedlot operators, processors (butchers and hotels) and consumers who performs different value chain activities. However the linkages among the value chain actors were weak.

The major production constraints which hindering the success of beef cattle value chain in the study areas were feed shortage, feed price increment, diseases outbreak, shortages of veterinary drugs, shortage of availability of water and poor management. Price instability, low price offered for farmers, brokers and less accessed to market information were the major market constraints in the study areas.

Dissemination of improved technologies such as AI, improved breeds, bull services and forage are essential in increasing the productivity of beef cattle in the study areas.

Mostly farmers sell their livestock when they need money for emergency purposes. To bring farmers to commercialization, encouraging farmers' business attitudes is necessary. So the concerned body should have to give attentions to encourage feedlot operators and create farmers awareness on modern fattening practices. This may play a central role to supply quality cattle for domestic slaughters/processor which at the present faced low beef quality standard and may also create job opportunities for unemployment. The government should have taken legal action and perform controlling activities on unlicensed traders and middlemen that have become burden on legal traders and reap higher profit without incurring any expenses.

\author{
Abbreviations \\ DLFRDO \\ OSCA \\ District Livestock and Fishery Development Office \\ SIDA \\ Oromia Saving Credit Association \\ Swedish International Development Agent
}

\section{Acknowledgements}

Above all, I thank the Almighty God for gave me health for the completion of this study. Next to God, I would like to express my heartfelt appreciation and gratitude goes to my major research advisor Dr. Lemma Zemedu and co-advisor Dr. Berhanu Gebremedhin for their constant instruction, guidance, intellectual feedback, enthusiasm and valuable suggestions from proposal writing to completion of full write up of my thesis.

\section{References}

Belete, A. et al. (2010). Cattle and meat production and marketing systems and opportunities for market orientation in Fogera woreda, Amhara region, Ethiopia. IPMS (Improving Productivity and Market Success) of Ethiopian Farmers Project working paper 19. ILRI, Nairobi, Kenya, 65pp.

Central Statistical Agency (2013). Agricultural Sample Survey, 2009/10 (2002EC), Report on Crop and Livestock Product Utilization, Statistical Bulletin 468. FDRE: Addis Ababa.

International Fund for Agricultural Development (IFAD) (2010). Technical Agreement Grant: Enhancing livelihoods of poor livestock keepers through increasing use of fodder. <http://fodder-adoptionproject.wikispaces.com/> accessed 14 July 2011.

Intergovernmental Authority on Development (IGAD) (2010). The Contribution of Livestock to the Ethiopian Economy -Part II. IGAD LPI Working Paper No. 02 -11. Roy Behnke, Odessa Centre, Great Wolford and United Kingdome.

Negassa, A. et al. (2011). Livestock Production and Marketing. Ethiopia Strategy Support Programme II (ESSP 
II) Working Paper 26.

Yamane, Taro, (1967), Statistics: An Introductory Analysis, 2nd Ed., New York: Harper and Row.

Table 1. Socio-economic characteristics of samples (categorical variables)

\begin{tabular}{|c|c|c|c|c|c|c|c|c|}
\hline \multirow[t]{2}{*}{ Variables } & \multirow[t]{2}{*}{ Items } & \multicolumn{2}{|c|}{$\operatorname{Dugda}(\mathrm{N}=67)$} & \multicolumn{2}{|c|}{$\operatorname{Bora}(\mathrm{N}=53)$} & \multicolumn{2}{|c|}{$\operatorname{Total}(\mathrm{N}=120)$} & \multirow[t]{2}{*}{$\chi^{2-\text { test }}$} \\
\hline & & $\mathrm{N}$ & $\%$ & $\mathrm{~N}$ & $\%$ & $\mathrm{~N}$ & $\%$ & \\
\hline \multirow[t]{2}{*}{$\operatorname{Sex}(\mathrm{HH})$} & Female & 12 & 18 & 5 & 10 & 17 & 14.17 & $1.8^{*}$ \\
\hline & Male & 55 & 82 & 48 & 90 & 103 & 85.83 & \\
\hline \multirow[t]{4}{*}{ Religion(HH) } & Orthodox & 60 & 90 & 49 & 92 & 109 & 91 & $7.4 * *$ \\
\hline & Muslim & 3 & 4 & & & 3 & 2.5 & \\
\hline & Catholic & 3 & 4 & & & 3 & 2.5 & \\
\hline & Protestant & 1 & 1.5 & 4 & 7.55 & 5 & 4.17 & \\
\hline \multirow[t]{2}{*}{ Education(HH) } & $(0=$ otherwise $)$ & 2 & 3 & 8 & 15 & 8.3 & & $5.7 * * *$ \\
\hline & $(1=$ formal $)$ & 65 & 97 & 45 & 85 & 91.7 & & \\
\hline \multirow[t]{3}{*}{ Marital Status(HH) } & Married & 63 & 94 & 50 & 94 & 113 & 94.17 & $2.1^{*}$ \\
\hline & Widowed & 2 & 3 & 3 & 6 & 5 & 4.17 & \\
\hline & Divorced & 2 & 3 & & & 2 & 1.66 & \\
\hline
\end{tabular}

$\mathrm{N}$ is number of respondents, $* * *, * *, *$ show level of significance at 5 and 10 percent

Source: Own computation from survey results (2017)

Table 2. Socio-economic characteristics of samples (Continuous variables)

\begin{tabular}{lccccccc}
\hline Variable & Dugda $(\mathrm{N}=67)$ & \multicolumn{2}{c}{ Bora $(\mathrm{N}=53)$} & \multicolumn{2}{c}{ Total $(\mathrm{N}=120)$} & $\mathrm{t}$-test \\
\hline & Mean & $\mathrm{SD}$ & Mean & $\mathrm{SD}$ & Mean & $\mathrm{SD}$ & \\
Age & 42.58 & 9.93 & 41.22 & 12.28 & 41.98 & 11.00 & -0.652 \\
Family size & 7 & 2.65 & 6 & 2.13 & 6 & 2.47 & $-1.95^{* *}$ \\
Farm experience & 13.97 & 9.54 & 15.19 & 11.01 & 14.51 & 10.19 & 0.635 \\
Distance to nearest woreda market & 12.1 & 2.8 & 8.4 & 1.8 & 10.5 & 3.04 & $-8.82^{* * *}$ \\
\hline
\end{tabular}

Table 3. Socio-economic characteristics of traders

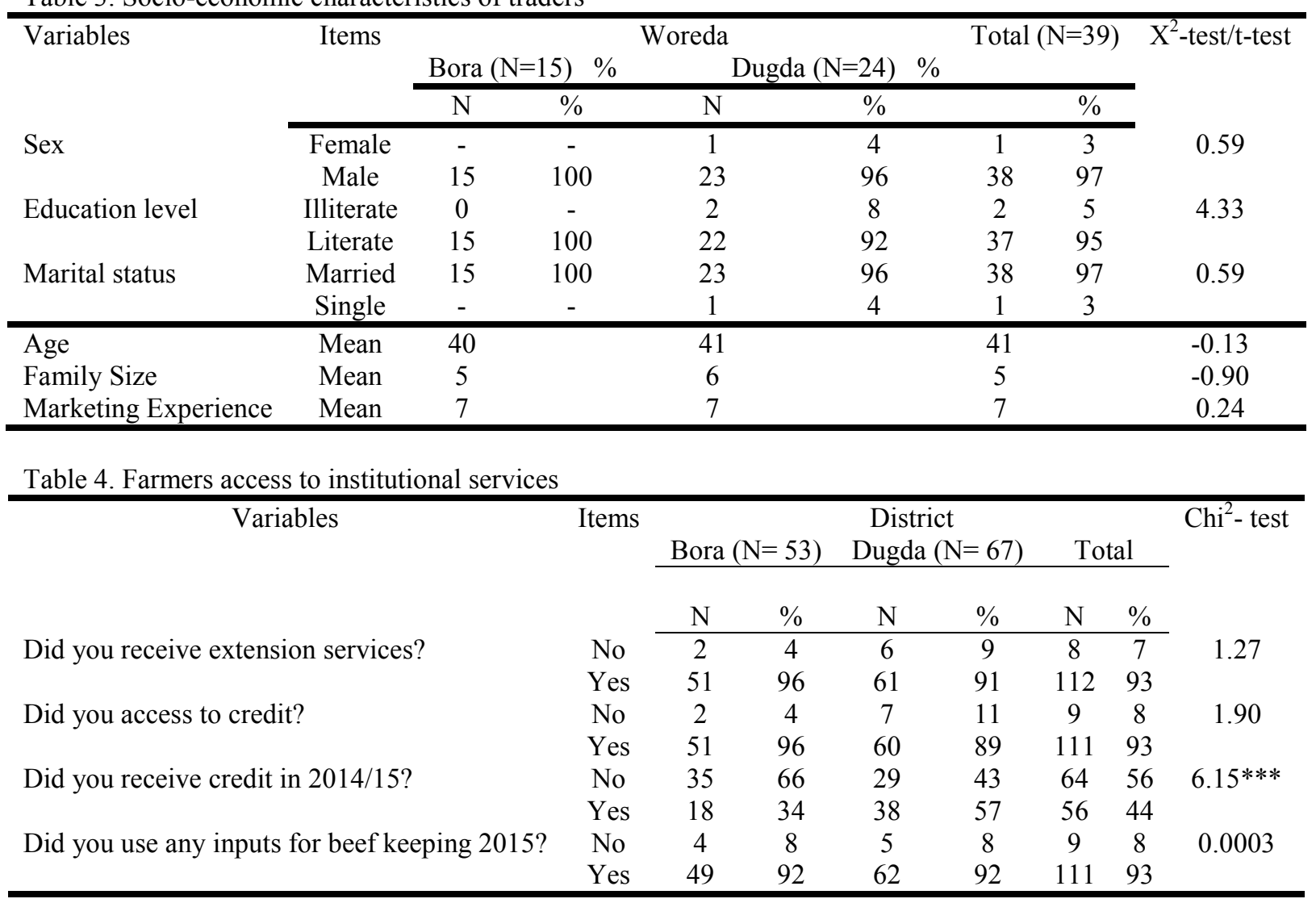


Table 5. Major beef cattle production constraints

\begin{tabular}{lccc}
\hline \multicolumn{1}{c}{ Major production constraints } & Frequency & \% & Rank \\
\hline Feed shortage & 113 & 94 & 1 \\
Feed price increment & 104 & 87 & 2 \\
Disease problems & 87 & 72 & 3 \\
Shortage of veterinary drugs & 53 & 44 & 5 \\
Shortage of availability of water & 44 & 40 & 6 \\
Poor management & 87 & 72 & 3 \\
\hline
\end{tabular}

Table 6. Major farmers market constraints

\begin{tabular}{lccc}
\hline Major market constraints & Frequency & $\mathbf{\%}$ & Rank \\
\hline Market price instability & 89 & $80 \%$ & 1 \\
Low price offered for farmers & 67 & $60 \%$ & 2 \\
Middlemen problem (Broker) & 46 & $41 \%$ & 4 \\
Less/no market information & 60 & $54 \%$ & 3 \\
\hline
\end{tabular}

Table 7. Beef cattle traders' constraints

\section{Major constraints}

Frequency

$\%$

Rank

Financial problem

20.3
11
25
33
25

\begin{tabular}{ll}
0.3 & $52 \%$ \\
11 & $28 \%$ \\
25 & $64 \%$ \\
33 & $84 \%$ \\
25 & $64 \%$ \\
\hline
\end{tabular}

3

Beef cattle supply shortage

Beef cattle quality problem

Lack of government support

Competition with unlicensed traders

4

2

1

2

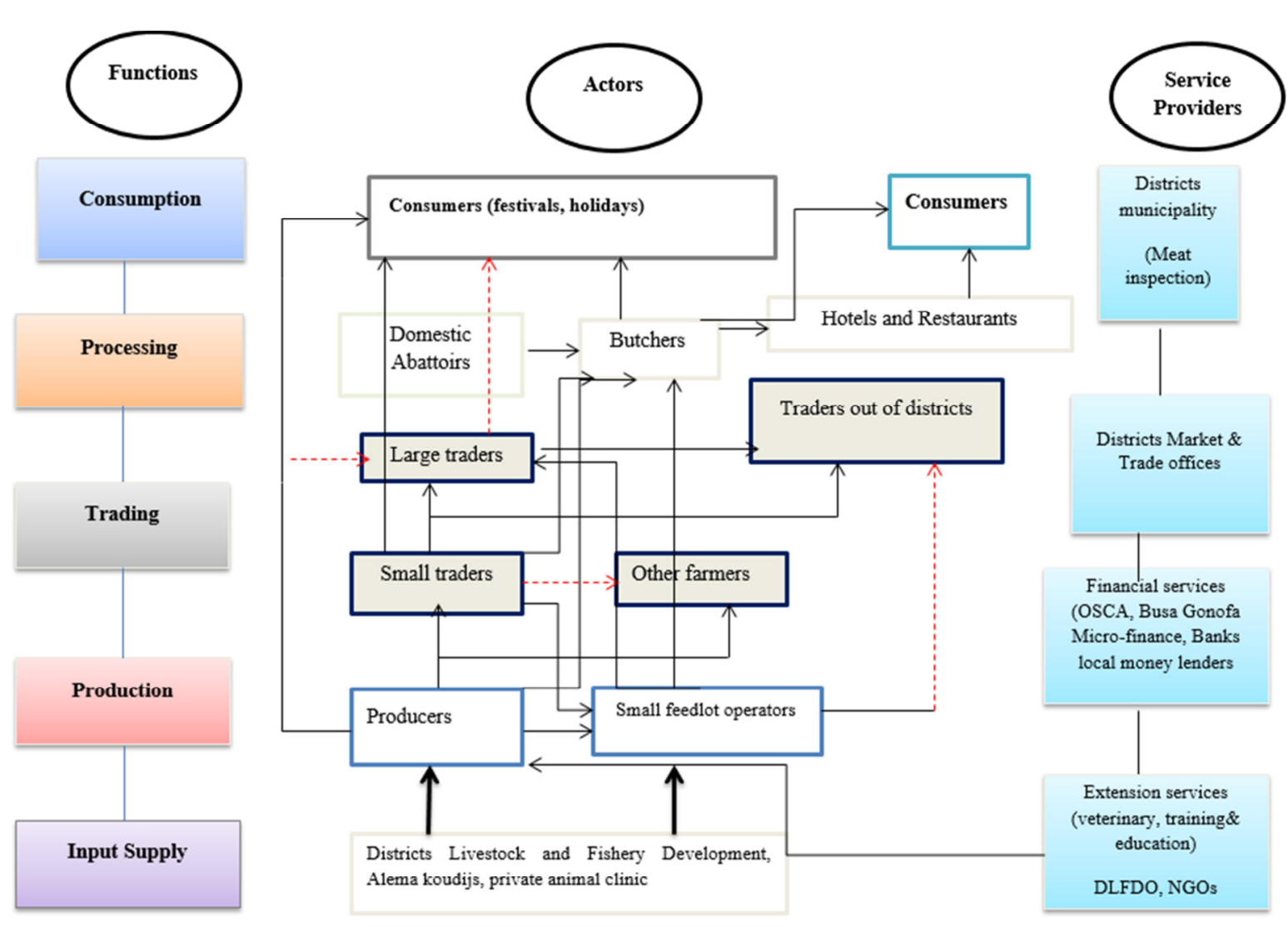

Figure 1. Beef cattle value chain map in Bora and Dugda Districts 